\author{
Economics Working Paper Series
}

2016/019

\title{
Board Expertise, Networked Boards and Environmental Performance
}

\author{
Swarnodeep Homroy and Aurélie Slechten
}

The Department of Economics

Lancaster University Management School

Lancaster LA1 4YX

UK

All rights reserved. Short sections of text, not to exceed two paragraphs, may be quoted without explicit permission, provided that full acknowledgement is given. 


\title{
Board Expertise, Networked Boards and Environmental Performance
}

\author{
Swarnodeep Homroy and Aurélie Slechten \\ Department of Economics, Lancaster University, LA1 4YX
}

November 23, 2016

\begin{abstract}
We analyze the role of board expertise in environmental issues (measured by the presence of non-executive directors with previous experience in environmental issues, EEDs) and director networks on GHG emissions. Using emission data of FTSE 350 firms, we show that the presence of EEDs on the board reduces GHG emissions. Also boards with better networked directors have better environmental performance. These associations are robust to alternative explanations - endogenous matching of firms and directors, general technical expertise of the board, and pro-active stacking in board composition. The results are consistent with the view that director skills and information spillovers through director networks add value.

Key words: Director Expertise, Director Networks, Emissions, Environmental Performance

JEL Classification: G34, G39, L14, L25, Q50
\end{abstract}

\section{Introduction}

Growing concerns about environmental sustainability has led to a large number of environmental regulations. These regulations aim to cut polluting emissions, phase out ozone-depleting chemicals, or provide cleaner water. Their success is likely to depend on how the corporate sector responds to these initiatives. Firms are under increasing institutional pressure to be environmentally responsible and most countries have now issued codes of good governance on environmental sustainability. Yet, there is little evidence on how firms internalize these pressures or how corporate governance impacts upon environmental performance of firms. In this paper, we examine the role of board expertise and director networks in shaping the environmental performance of firms. 
The board of directors forms the "apex" of decision making and corporate control, primarily tasked with monitoring and advising senior management (Fama and Jensen, 1983; Adams, Hermalin and Weisbach, 2010). Whilst the monitoring role of the board of directors has been extensively researched, recent work highlights the importance of the advisory role, specifically when directors have relevant expertise and when the regulatory environment is complex (Dass, Kini, Nanda, Onal, and Wang, 2014; Coles, Daniel and Naveen, 2008). This is particularly true for environmental issues which are likely to involve large capital expenditures with uncertain returns, are institutionally complex, and can have long-term value implications (Konar and Cohen, 2001). Therefore, the expertise and networks of the board of directors and the governance mechanism within a firm are likely to affect environmental performance in many ways. First, a director with environmental experience (henceforth EEDs) can narrow the information gap between the board and the management (Pfeiffer and Salancik, 1978). At the same time, since boards do most of their work through committees, firms are more likely to benefit from related expertise of directors if they have board level committees focused on environmental performance (Adams, 2003; Billmoria and Piderit, 1994; Laux and Laux, 2009).

Second, in forming a strategic response to complex institutional regulations, firms can leverage knowledge across organizational boundaries, through the networks of individual directors. We focus on the directors network formed by shared directorship: two directors are connected if they sit on the same board in a given year. On one hand, boards with better-networked directors (i.e. directors with better-quality connections) are likely to have a comparative advantage because they may have access to better information on environmental technology (Larcker, So, and Wang, 2013). Firms can learn about environmentally efficient production technology, their implementation costs, etc. through their directors' networks. On the other hand it is possible for value-destroying practices to be propagated through director networks: directors sitting on the boards of many different firms spend less time on an individual firm, or engage in collusive practices on environmental sustainability issues (Fich and Shivdasani, 2006).

Against this backdrop, the objective of this paper is to answer the following questions: a) how does board expertise affect a firm's environmental performance? and b) how do board networks 
influence environmental performance? To this end, we use (i) greenhouse gas data (normalized by the permissible thresholds of each type of pollutant) from the European Pollutant Release and Transfer Register, as a measure of a firm's environmental performance, and (ii) information on the board composition and director networks of FTSE 350 firms from BoardEx. Our sample comprises an unbalanced panel of 274 firms for the period 2006-2014. In estimating the effects on environmental performance of board expertise and director networks, it is important to control for potential bias introduced by endogenous appointment of EEDs or better-networked directors in certain firms. In addition to adjusting for firm and year fixed effects to mitigate time-invariant omitted variable bias, we control for a range of firm and industry characteristics.

When investigating whether the presence of EEDs and board level committees on sustainable issues affect environmental performance, we also use two-stage least square estimation to control for bias induced by time-varying unobservables. We instrument the appointment of EEDs with a measure of supply of potential directors with environmental expertise. A higher supply of directors with environmental expertise is likely to lower the cost of appointing such directors on boards, but should not directly influence an individual firm's environmental performance. We find an economically meaningful effect of having EEDs on the board, particularly if these directors are members of board-level committees focused on environmental issues. To quantify, when firms have environmental directors on board, GHG emissions are lower by 0.16 standard deviations; and when firms have EEDs on environmental committees, GHG emissions are lower by 0.19 standard deviations. These results are robust to different classifications of EEDs and board committees for environmental issues.

To address the second question, we use four centrality measures (viz. degree, closeness, betweenness, and eigenvector) that capture different aspects of a director's centrality (or importance) in the network formed by shared directorship. We then aggregate each measure at the board level to get a measure of the board centrality and examine its impact on the firm's GHG emissions. We find that better-networked boards have lower GHG emissions. For example, a one standard deviation increase in the degree is associated with 0.20 standard deviation decrease in GHG emissions. However, it is possible that this result is driven by endogenous 
selection of more skilled directors to firms with better environmental performance. Masulis and Mobbs (2011) show that endogenous matching on director skills can drive the results of board connections and financial performance of firms.

We perform an array of tests to examine possible endogeneity in board composition and director networks. These tests also allow us to examine whether the negative association of boards networks and GHG emissions is driven by better access to information or better monitoring. First, we restrict the sample to a subset of firms with unchanged board composition from the previous to the current year. In the absence of new director appointments, the negative association of board networks and GHG emissions still holds. This could be due to better access to network, or better monitoring through changes in first-degree connections. Second, we select a subsample of firms with no change in board composition and no changes in first degree connections from the previous to the current year. Again, the statistically significant negative association of board networks with GHG emissions still holds. However, this time, this negative association cannot be explained by a better monitoring of directors on the board of the focal firm: as first and second degree connections do not change, these directors are sitting on the same number of boards. The results suggest that better-networked boards are able to reduce the firm's GHG emissions through access to better information.

Collectively, the results suggest that board expertise and network have economically meaningful effects upon the environmental performance of firms. These results add to a few different strands of economics and finance literature. First, it is related to the literature on voluntary measures taken by firms on environmental sustainability. The prior literature has examined the motivations of firms to participate in voluntary environmental management and climate change programmes, and the implications for environmental performance (Anton, Deltas and Khanna, 2004; Dasgupta, Hettige and Wheeler, 2000; Fisher-Vanden and Thorburn, 2011; King and Lenox, 2000). These papers have highlighted the impact of firm size, profitability, access to financing, regulatory and stakeholder pressures on the uptake on voluntary environmental practices by firms. While it is widely acknowledged that environmental strategy is decided at the board level, there is limited discussion so far about how the board governance affects firms' 
environmental performance. Ortiz-de-Mandojana et al. (2012) show that board networks has a positive impact on the adoption of proactive environmental strategies by firm. However, they consider only one aspect of centrality (i.e. the degree) while we look at the impact of four different measures. de Villiers et al. (2011) report better environmental performance for firms with larger and more independent boards. Two other papers (Kassinis and Vafeas, 2002; McKendall et al., 1999) examine the relationship between board characteristics and the number of violations of environmental legislation. Both studies document evidence of a positive relationship between environmental violations and the combined stock ownership of corporate officers and directors. In addition, Kassinis and Vafeas (2002) also highlight the importance of networked boards, and find weak evidence that prosecuted firms have directors with fewer multiple directorships. While these studies provide some insights into how boards affect compliance with environmental legislation, they do not consider individual director characteristics (i.e. expertise or network centrality) that may help the firm pursue better environmental performance. A key distinction of our paper is that we focus on the director level characteristics, like directors' skills and experience and network connections, that might affect environmental performance. Furthermore, we add to this literature by using a quantitative and comparable measure of environmental performance, i.e. the level of greenhouse gas emissions. Majority of studies use an aggregated score-based measure (KLD) as a proxy for environmental performance (Di Giuli and Kostovetsky, 2014). Whilst this provides a measure to ordinally rank order firms, it subsumes the underlying distribution of emissions. Some other studies use negative environmental events like oil-spills, government enforcement actions, lawsuits, etc. (Klassen and McLaughlin, 1996; Karpoff, Lott, and Rankine, 1999; Konar and Cohen, 2001). These measures, whilst useful in studying a particular type of pollution or an event, doesn't provide an objective and comparable measure of firms' environmental performance.

Second, our paper is related to the literature on the advisory role of directors and directors' expertise. The financial, legal, industry, and political expertise of directors have been well studied (Güner, Malmendier and Tate, 2008; Goldman, Rocholl, and So, 2009; Dass et al. 2014). These papers provide evidence that firms can benefit from the related expertise of directors. On 
a similar note, Adams and Ferreira (2007) and Masulis and Mobbs (2011) suggest that executive directors can be concerned with monitoring and therefore conceal information. Specifically, our paper focuses on directors experience in environmental sustainability matters. We argue that directors with specific skills related to environmental management can widen the information set available to the board.

Third, we contribute to the literature on board networks. Existing literature studies the effect of director/CEO connections on financial performance of firms (Hwang and Kim, 2009; Fich and White, 2003). There is evidence on the impact of social network of directors on venture capital (Hochberg, Ljungqvist, and Lu, 2007; Lindsey, 2008), managerial compensation (Hwang and Kim, 2009), and lending markets (Garmaise and Moskowitz, 2003). Bizjak, Lemmon, and Whitby (2009) find that social connections between directors are positively associated with options backdating. More closely aligned to this paper is the bourgeoning literature on innovation economics and corporate governance that looks at how firm investment into innovation is affected by CEO types or characteristics (e.g. Acemoglu, Akcigit and Celik, 2014; Galasso and Simcoe, 2011; Gomes-Casseres et al., 2006). For example, Gomes-Casseres et al. (2006) show that innovations and patent filings are associated with board network connections. Our paper adds to this literature in examining how knowledge flow through director networks affects GHG emissions.

Finally, these results are timely in light of the increasing mandatory environmental impact disclosures for firms in the developed economies. For example, corporate environmental disclosures are receiving increased scrutiny by Security and Exchange Commission in the United States. Similarly, under the Companies Act 2006, listed companies in the U.K. are required to report GHG emissions from October 2013. In particular, these regulations makes the directors responsible for the environmental impact of the firm. Such individual accountability is only justified if directors are in a position to influence environmental performance. We show that through related expertise and networks, directors improve environmental performance in terms of GHG emissions.

The rest of the paper unfolds as follows: in section 2, we describes the data and empirical 
strategy; section 3 presents the headline results, and section 4 concludes.

\section{Data and Variables}

In this section we discuss the data sources, variables construction and sample selection for our empirical tests.

\subsection{DATA DESCRIPTION}

Our sample is taken from listed UK firms featured in the FTSE 350 index over the period 2006 to 2014. From Datastream we collect information on performance, size, risk in the operating and information environment and industry classifications. We augment this with information on individual directors, board composition and board networks of these firms using BoardEx. Finally, firm-level environmental emissions data are obtained from the European Pollutant Release and Transfer Register (E-PRTR).

\subsubsection{Sample Selection}

To be included in our sample, firms have to feature in the FTSE 350 for at least two consecutive years, have the full set of board characteristics, and relevant financial data available. With these constraints, we have an unbalanced panel of 375 firms with 3328 firm-year observations.

From this sample we drop firms for which no directors have any network connections. We augment the FTSE 350 sample with network centrality measures of individual directors using information available from BoardEx. To calculate the network centrality of individual directors, we use shared directorships from all quoted boards in Europe. As an additional sample selection criterion, we require that firms have information on GHG emissions for all years (2007-2014). This restricts our sample to an unbalanced panel of 313 firms with 4,143 firm-year and 18,098 director-year observations.

Finally, not all industries pollute through GHG emissions. We restrict our sample to firms from GHG emitting industries only, and exclude firms in Financial and IT industries. Our final 
sample is therefore comprised an unbalanced panel of 274 firms for the years 2006-2014 with 3,244 firm year and 16,212 director-year observations. Table I summaries the key variables of the sample.

[Table I near here]

\subsection{BOARD EXPERTISE AND BOARD NETWORK}

\subsubsection{Board Expertise}

We identify three different sources of director expertise in environmental issues. First, we use information provided by BoardEx on individual directors' background to control for specific experience in environmental sustainability. Following the sample selection protocol used by Berrone and Gomez-Mejia (2009), we classify a director as EED if the job description of a previous role contain keywords like "environment", "ecology", "pollution", "sustainable", etc. ${ }^{1}$ Information from committee formations allows us to identify directors with experience on board sub-committees that have an environment/pollution control focus. Finally, we use information on awards for, and recognition of individual directors on environmental issues. ${ }^{2}$ It is possible that we do not have complete information on environmental sustainability. related roles, and environment related awards of directors, and this can be a likely source of attenuation bias. In that regard, our results will be conservative estimates of the impact of these variables on environmental performance.

For the purpose of encoding the environmental experience of directors, we use the subsample of non-executive independent directors: individuals who are less aligned with management have a lower incentive to maximise short term profits and are more likely to influence the environmental performance (Byrd and Hickman, 1992; Johnson and Greening, 1999). Our measure of director expertise (denoted by EED) is a binary indicator of environmental expertise which is equal to one if any of the three measures discussed above is relevant to that director in a given year.

\footnotetext{
${ }^{1}$ All variants of these words is used to encode environmental experience. A complete list of these key words are presented in appendix 2 .

${ }^{2}$ Such awards include environmental leadership awards, global cross millennium awards for corporate environmental leadership, etc.
} 
To give an example, independent non-executive director Patrick Grasby of Drax Group PLC, an electrical power generation company, has previous experience of being on the environmental sustainability committee in OPG Power Ventures group. He is therefore encoded in our sample as an EED. On average a firm has 1.4 EEDs. We then aggregate this indicator at the board level in the following way: we use a binary indicator (EED dummy) which is equal to one if at least one director on the board is EED.

We then compute the aggregate supply of EEDs in each industry, which is the sum of all directors with some environmental experience and sitting on the board of firms in that industry in each year. From table III and Figure 1, the aggregate supply of EEDs has increased over the years from 2010.

We also define an indicator for the presence of an environmental committee on the board. This measure captures the importance of environmental performance to a firm: a firm with a board committee on environmental issues is likely to attach more importance to environmental performance than firms that do not have such committees.

[Table II near here]

[Figure 1 near here]

An econometric concern of using environmental experience of directors is the potential bias induced by assortative sorting. Two situations are plausible. First, the demand for EEDs can be higher in firms (or industries) with higher GHG emissions. Therefore director appointment with environmental expertise is likely to be more prevalent in high-pollution industries. Even though this could induce biased estimates, such negative assortative sorting will only reinforce the importance of director experience in environmental sustainability. Second, and more importantly, it may be possible that the supply of EEDs is constrained for high polluting industries, i.e. out of reputational concerns, EEDs do not accept offers from polluting firms. If so, the effect of EEDs on GHG emissions will be an artefact of this positive sorting mechanism. In table II, we present the industry breakdown of GHG emissions and aggregate supply of EEDs. There is little evidence of supply constraint of such directors in high-polluting industries like Energy and 
Industrial production: about 37.25 percent of all EEDs are in the energy and industrial production sectors. The distribution of EEDs partially mitigates concerns about assortative sorting. Nevertheless, we use a 2SLS approach, where we instrument the appointment of environmental directors on a board by the supply of such directors in the same industry of the firm The underlying assumption is that firms appoint directors with environmental expertise from within the same industry to leverage industry-specific knowledge. ${ }^{3}$ The theoretical underpinning of this approach is that if the supply of EEDs in the industry increases, the cost to firms for appointing such directors decrease, but it doesn't directly impact upon GHG emissions at the firm level.

[Table III near here]

\subsubsection{Board Networks}

As discussed in section 1, we use information from BoardEx to build the director networks that shared directorship gives rise to. For each year, each individual director is a node, and two directors (or nodes) $i$ and $j$ are connected if they sit on at least one board $k$ in time $t$. The connections between individual directors define the network. Mathematically, a network is a square "adjacency" matrix where each cell indicates whether two individual directors are connected. As we use undirected networks whereby the connection between two directors has no directional character (i.e. there is no assumption on the direction of the flow of information between two directors), the adjacency matrix is symmetric. Note that for the same reason as for environmental expertise, we construct our network using information on the independent non-executive directors only.

Our objective is to analyze how the relative importance or centrality of directors in the network affects a firm's environmental performance. The concept of connections quality or centrality is multidimensional. We focus on four basic dimensions widely used in the network literature (see Jackson, 2010). The "Degree" or the number of unique connections to other directors gives us the number of channels of information available to a given director. Second,

\footnotetext{
${ }^{3}$ If this assumption is relaxed, and environmental directors are appointed from across industry classifications, the instrument will lack power in the first-stage estimates.
} 
"Closeness" measures how easily a director can access information. It measures of the shortest path between two directors. Third, a director is more central in a network if it connects more directors. This measure, "Betweenness", emphasizes the role of a director as intermediary in a given network. Finally, a director is also well-networked if he is connected to individual directors who are also well-networked. Eigenvector measures director's centrality based on the centrality of his first degree connections. Formal definitions of these centrality measures can be found in appendix 3 .

To obtain a measure of centrality at the board-level, we compute average centrality measures for all the directors on a specific board in a given year. In table III, we provide the time series of our centrality measures at the board level. On average an individual firm is linked to 6 other firms (Degree) and this remains stable over time. The average closeness and betweenness measures of our sample are also stable over time. Given that the time-series of the aggregate network is stable, our concern that the empirical results could be an artefact of the secular increase in aggregate board network is mitigated. In table II, we present the industry-wise breakdown of the network centrality measures. Industrial production sector has the highest degree and closeness. Eigenvector is the highest for the Energy sector.

There are a few econometric issues with using network centrality measures. First, larger firms tend to have better-networked boards (Larcker, et al. 2013). We purge the firm size effects by regressing the four centrality measures on the log of firm size and the square of the log of firm size, and using the residuals as size-adjusted centrality measures. Further, if board centrality in the network is positively correlated with director quality, then our empirical test will simply capture the effect of better quality directors on GHG emissions. Ideally, an exogeneous shock is required to establish the effect of board network on GHG emissions. However, an exogeneous shock to board network that doesn't otherwise affect GHG emissions is not immediately obvious. In section 3.2, we discuss our approach to address this concern. 


\subsubsection{Control Variables}

We use a range of firm and industry-level observables in our baseline estimates to control for confounding factors (i.e. sales, board size, Return on Assets, board independence, etc.). For example, appointment of EEDs and board network may vary by industry competitiveness, risk in firm's operating environment, and capital structures of the firm. Therefore in our baseline estimates we control for industry competitiveness by HHI, volatility, and leverage.

Finally, to mitigate concerns that appointment of EEDs are non-random, we present univariate differences for all observable firm characteristics for firms with and without EEDs. Firms with EEDs have larger boards, and lower centrality measures, and lower GHG emissions. However, there are no statistically significant differences for any other variables, like R\&D expenses. Univariate results are presented in table IV.

[Table IV near here]

\subsection{MEASURING ENVIRONMENTAL PERFORMANCE}

As a measure of firms' environmental performance, we use firms' GHG emission data from the E-PRTR. The E-PRTR provides annual pollution data from more than 30, 000 facilities over the period 2007-2012 across several industrial sectors. It provides data on releases of pollutants to air, water and land as well as off-site transfers of waste and of pollutants in waste water from 93 key pollutants, including heavy metals, pesticide, greenhouse gases and dioxins. The main advantage of the register is that data is comparable across countries and pollutants because data collection and reporting is standardised over all pollutants in all countries (see appendix 1 for details).

Pollution data in the E-PRTR is at the facility-level - where a facility is an operation unit of a firm focused on a narrowly defined process like packaging, bottling, etc. To arrive at the firm-level emission data, we aggregate GHG emissions for all European facilities of a FTSE 350 firm. This aggregation process requires multi-level matching. EPRTR reports the parent firm of each facility. We first aggregate the information of all facilities that have the same parent firm. 
281 of these parent companies reported by the E-PRTR are not publicly listed firms themselves, but are wholly owned subsidiaries of listed firms. We map these subsidiaries to the listed firms by using information available from Orisis. This matching exercise yields 89 unmatched firms. We manually supplement the missing information on parent firms from publicly available news, and drop from the sample where no information on GHG emissions are available. This leads to omission of 40 firms.

We validate our matching algorithm by comparing our agglomerated GHG emission with the GHG emission data available from Datastream. We use the ENERDP123 field in Datastream that reports the annual total GHG emissions as $\mathrm{CO}_{2}$ equivalents. By using our agglomeration algorithm, we have improved upon the coverage of Datastream by $32.37 \%$ : on average Datastream reports GHG emissions for 207 firms across the sample period whereas we could calculate GHG emissions of 274 firms. The correlation of the GHG measure reported by Datastream and our measure is 0.809. Given the wider coverage of our measure, we use our calculation GHG emission data in the baseline regressions, and test for the robustness of our results using the sub-sample of firms with GHG emission data from Datastream. ${ }^{4}$

\section{Empirical Analysis}

In this section we examine the board level characteristics that influence GHG emissions of firms. We study two aspects of the board: the expertise of the directors in environmental sustainability. issues, and the centrality of directors in the network formed by shared directorships.

\subsection{BOARD EXPERTISE AND ENVIRONMENTAL PERFORMANCE}

The central hypothesis is that the presence of EEDs on a board affects the environmental performance of firms. We present the results in table $\mathrm{V}$ with robust standard errors clustered at firm level. We estimate the following regression equation:

\footnotetext{
${ }^{4}$ GHG emissions data for 2013 and 2014 come from Datastream because these years were not available in the E-PRTR.
} 


$$
G H G_{i t}=\alpha_{i}+\delta_{t}+\boldsymbol{\beta}^{T} \mathbf{E x p}_{i t-1}+\boldsymbol{\gamma}^{T} \mathbf{Z}_{i t}+\epsilon
$$

where $i$ denotes the firm and $t$ the year. Variables are defined as follows: $G H G_{i t}$ is the total GHG emissions of firm $i$ in year $t$ (the dependent variable), $\alpha_{i}$ is the firm fixed effect, $\delta_{t}$ is the year fixed effect. Firm-fixed effects isolate the effect of board expertise on GHG emissions. Vector $\mathbf{Z}_{i t}$ contains various firm and board level control variables (board size, percentage of non-executive directors, log of total sales, ROA, percentage of institutional shareholding).

The vector $\operatorname{Exp}_{i t-1}$ contains the variables of interest related to environmental expertise for firm $i$ in year $t-1$ : the binary variable EED dummy, which is equal to one if at least one director on the board has some environmental experience, the binary variable Environmental Committee and the interaction term. As denoted by the subscripts, environmental expertise is measured in the year preceding GHG emissions. In establishing an association between board characteristics and environmental performance (and later for network centrality and environmental performance), reverse causal associations whereby an individual directors with a background in environmental sustainability. accepts positions in firms with better performance need close attention. We try to mitigate this concern in the following ways. First, we lag the independent variables by one year. This identifies board characteristics that pre-date emissions by at least one year. Second, our baseline estimates include year and firm fixed effects to control for time-invariant unobservable firm characteristics that might simultaneously impact upon GHG emissions and the appointment of directors with environmental expertise.

From column 1: the presence of at least one director with environmental experience on the board is associated with lower GHG emissions. In column (2) we add the indicator for the presence of an environmental committee on the board. In this specification, we are trying to isolate the effect of director expertise from the firm's intrinsic focus on environmental issues. Both director expertise and the presence of an environmental committee seems to be negatively associated with GHG emissions. Therefore the effect of board expertise on GHG emissions persists after controlling for the importance of environmental performance to the firm. Finally, in 
column 3 we add an interaction of board expertise in environmental issues and the presence of an environmental committee. This captures the effect of appointing a director with environmental expertise on environmental committees. In addition to environmental committees and environmental expertise, the interaction is also negatively associated with GHG emissions. In gist, these estimates suggest that board expertise on environmental sustainability. is associated with lower GHG emissions. Firms with enabling mechanisms on the board in the form of board committees focussed on environmental issues gain incremental benefits in environmental performance. To quantify: a one standard deviation increase in the proportion of EEDs leads to a 0.16 standard deviations decrease in GHG emissions. ${ }^{5}$

\section{[Table V near here]}

A remaining concern is that presence of EEDs on boards can be sticky at the firm level over time, and appointments of EEDs can be driven by time-varying unobservable characteristics or shocks. For example, it could be possible that appointment of directors with environmental expertise happens around other major changes in the firms. We find in our sample, 77 percent, 72 percent and 70 percent of the firms that had at least one EED in period $t$ also have them in periods $t+1, t+2, t+3$ respectively. Only 13 percent of CEO turnovers, and 7 percent of M\&As coincide with the change in firms status of having an environmental director or not. This partially addresses the concern that unobserved shocks are changing both GHG emissions and the appointment of environmental directors. It has been argued cases of time-persistent regressors, instrumental variables regressions are preferred over fixed-effects models (Angrist and Pischke, 2008; Dass et al., 2014).

To ensure that the baseline results presented above are not driven by endogeneity in environmental performance, we estimate an IV-regression where we use the supply of EEDs as an exogenous source of variation in the firm-level appointment of such directors. Our instrument is Ln(industry supply of environmental directors per seat). The supply is measured by identifying

\footnotetext{
${ }^{5}$ The economic effect is arrived at using the ratio of the standard deviations of EEDs and GHG emissions, and multiplying this by the coefficient of EED from column (1) of table 5. GHG emissions are expressed in /1,000,000 tonnes.
} 
and summing all EEDs in one specific industry. This is then scaled by the aggregate board size in the same industry. A greater supply of EEDs is likely to reduce the search cost for such appointments, but there is no obvious direct relationship between this supply measure and the GHG emissions of individual firms. Moreover, the scaling by aggregate board size implicitly controls for industry effects.

[Table VI near here]

We present the 2SLS results in table VI for the just identified models. This is essentially a Heckman-type selection model where the dependent variable in the first stage is the binary indicator EED. First, we check that the instrument is relevant in the first stage regressions which are presented in column (1). The instrument is positively associated with the board expertise in environmental affairs, and this association is statistically significant. Further, the F-statistic of the first stage regression is greater than 10, thereby mitigating concerns about weak instrument. We present the second stage results in columns 2-4 with heteroscedasticity robust standard errors. The parameter estimates of board expertise in environmental issues is negative and is statistically significant. Therefore our results do not seem to be driven by potential endogenous selection of EEDs to boards.

\subsection{DIRECTOR NETWORK AND ENVIRONMENTAL PERFORMANCE}

The second hypothesis we are testing is whether directors' centrality in the network affects environmental performance of firms. We present the results in table VI with robust standard errors clustered at firm level. We estimate the following regression equation:

$$
G H G_{i t}=\alpha_{i}+\delta_{t}+\beta \times N e t w o r k_{i t-1}+\gamma^{T} \mathbf{Z}_{i t}+\epsilon
$$

where $i$ denotes the firm and $t$ the year. Variables are defined as follows: $G H G_{i t}$ is the total GHG emissions of firm $i$ in year $t, \alpha_{i}$ is the firm fixed effect, $\delta_{t}$ is the year fixed effect. These

fixed effects are included to control for time-invariant unobservable firm characteristics that 
might simultaneously impact upon GHG emissions and network centrality measures. Vector $\mathbf{Z}_{i t}$ contains same firm and board level control variables as in the previous section.

The variable $N e t w o r k_{i t-1}$ is one of the four centrality measures previously defined for firm $i$ in year $t-1$ : degree, closeness, betweenness and eigenvector. As explained before, we use size-adjusted centrality measures in all our specifications, and lag the independent variables by one year. ${ }^{6}$

We present the results in table VII, where in column (1) we present the OLS results with Degree as our measure of centrality; in columns (2)-(5) we present the fixed effects estimates with Degree, Closeness, Betweenness, and Eigenvector, respectively. We find the firms with a higher degree have lower GHG emissions, but this association is not statistically significant in the within-firm estimates. All other measures of centrality are negatively associated with GHG emissions, and such associations are statistically significant. To quantify, one standard deviation increase in degree centrality leads to 0.19 standard deviations decrease in GHG emissions.

There are two possible explanations for how director networks may affect environmental performance: (1) financial performance and environmental performance may be correlated. Therefore more successful firms attract more networked directors; or (2) information spillover from the board networks influences environmental strategy, and performance. If director quality is positively associated with the size of her network, this may bias our estimates with the centrality measures (Masulis and Mobbs, 2012). In this section, we perform a series of tests to examine the likelihood that our results are driven by such associations.

[Table VII near here]

We reduce our analysis to a subset of firms whose board composition did not change from the previous year. This restricts the possibility of assortative sorting, whilst allowing for variations in network centrality through changes in board composition of other firms in the network. The results for the sample with this restriction are presented in panel A of table VIII. We further

\footnotetext{
${ }^{6}$ The reason why we dot include all the centrality measures in the same regression but add them one at a time is that they are highly correlated.
} 
restrict our sample to firms whose board composition as well as first-degree network connections did not change from $t-1$ to $t$. Any change in the board centrality measures is likely to be caused by changes in centrality of other boards. Results with these restrictions are presented in panel B of table VIII. The results remain economically significant, but vary in statistical significance due to smaller sample size.

\section{[Table VIII near here]}

These results could be due to two competing reasons. First, better-networked boards have access to information. Second, sitting on multiple boards is a way of monitoring a director's action because individual members are now exposed to more peers. Whilst we can not establish a causal link, the empirical setting of table VIII makes some attempts towards disentangling these two channels. In panel A, we report negative association of better-networked boards with GHG emissions in a sample of unchanged board composition. In this sample, any variation in the centrality measure is caused by change in the first degree connections. Additional first degree connections are likely to simultaneously introduce better information and better monitoring to the focal board. In panel B, we use a further restriction of unchanged first degree connection. This allows us to observe variation in the centrality measure through variation in second degree connections. Changes in second degree connections are likely to increase the access to information, but may not have a direct effect on the monitoring of the focal firm. Therefore we interpret the results of table VIII to be supportive of the view that better-networked boards improve performance in terms of GHG emissions because of better access to information.

\subsection{ROBUSTNESS}

In this section we present the robustness of our results to alternate explanations and potential misclassifications. The results are presented in table IX. 


\subsubsection{Alternate Classifications of Environmental Directors}

By our classification of environmental experience, we may be employing an imperfect proxy of technical expertise. In other words, EEDs could potentially be a subset of directors with technical expertise. If so, we should get a stronger effect by using a measure of technical expertise. From information on their education and career background we construct a measure of technical directors where directors have financial, engineering, legal and technology expertise, in addition to environmental expertise. Using this measure of board expertise, we reestimate our baseline specifications. The coefficient on this measure of technical expertise is negative but not statistically significant at conventional levels. Therefore, it does not seems that our baseline results are capturing the effect of technical expertise. Directors with specific expertise in environmental experience seems to have an effect on GHG emissions. The results are presented in column (1) of table IX.

\subsubsection{Impact of CEO-EEDs}

Fich (2005) and Fahlenbrach, Low and Stulz (2010) show that firms can benefit from appointing directors who are CEOs of other firms. We identify the subsample of those firm-years where there is at least one independent non-executive director who is a CEO of another listed firm. Within this subsample, we identify CEO-EEDs. A large proportion of EEDs, (78\%) are not CEOs of other firms. We reestimate our baseline specifications discussed in section 3.1 with an indicator for CEO-environmental experience. We find that presence of both CEO environmental directors and non-CEO environmental directors are associated with lower GHG emissions. The results are presented in columns (2) and (3) of table IX.

[Table IX near here]

\subsubsection{Alternate measures of environmental performance}

Whilst GHG emission is the most pressing of environmental concerns, there are other measures of environmental performance that needs to be considered. In alternate specifications, we test 
for the robustness of our results using particulate matters, and effluent release as measures of environmental performance. ${ }^{7}$ The results are consistent with our baseline estimates, albeit with smaller sample sizes. These results are unreported in the interests of brevity but are available upon request.

\section{Conclusion}

One of the major concerns of our times is to integrate economic and environmental wellbeing. There is increasing institutional pressure on firms to be environmentally responsible. We examine two possible channels through which firms can internalize such institutional costs. Explicitly, we investigate the advisory function of the board of directors. EEDs have skills that suits them to provide information and strategic advise on matters related to environmental sustainability. Similarly, boards can leverage knowledge on environmental strategies through shared directorships. For example, better-networked boards can improve a firm's ability to respond to shocks in environmental technology or anticipate regulatory changes on sustainability. We examine whether board expertise and centrality in the network explain variations in the subsequent environmental performance of firms. After controlling for endogeneity concerns, we find that EEDs have an economically significant impact on GHG emissions: firms with board expertise in environmental sustainability have lower GHG emissions. We test for alternative explanations, and our results suggest that the effect of EEDs is likely to be a specific expertise effect rather than general technical skills. We also find that firms with better-networked directors have lower GHG emissions. Our results also support the view that firms with better-networked directors are able to improve performance in terms of GHG emissions through a better access to information.

In the light of the above findings, an obvious question arises: why don't all firms appoint EEDs given the growing importance of environmental sustainability? This could be due to a number of reasons. First, appointment of directors with a set of specific skills has opportunity costs. Appointing a director with environmental skills might mean keeping out a director with

\footnotetext{
${ }^{7}$ We use information on both harazardous and non-hazardous effluent releases to land and water.
} 
general or other specific skills which might be valuable to the firm. Second, if environmental technology is industry-specific then anti-trust laws may prohibit firms competing in the same product market to have shared directors. This constrains the supply of environmental directors to firms. Therefore such appointments are likely to be endogenous selections where the benefits of such appointments outweighs the cost. Similarly, our findings do not suggest that a more connected network can lead to lower GHG emissions for all firms. Board connections are constrained by both demand and supply side frictions: constraints on number of board positions for a director, number of board seats available, cost of replacement, etc. A director position within the network also depends on director appointment in other firms, which an individual firm has little control over. Thus not all firms can, and will attempt to improve their centrality in the network.

Acknowledgement: The authors thank Molly-Rose Ives, Simon Spavound and Rhys Wheeler for research assistance. We also thank Shantanu Banerjee, Patricia Boyallian, Estelle Cantillon, Sudipto Dasgupta, Vikram Nanda, Amiyatosh Purnanandam, and Ian Walker for their comments and suggestions. Financial assistance for Lancaster University pump priming grant is gratefully acknowledged.

\section{References}

[1] Acemoglu, D., U. Akcigit, and M.A. Celik, 2014, Young, Restless and Creative: Openness to Disruption and Creative Innovations, Working Paper.

[2] Adams, R.B., Hermalin, B.E., and Weisbach, M.S. (2010) The role of board of directors in corporate governance: a conceptual framework and survey, Journal of Economic Literature, 48, pp. 58-107.

[3] Adams, R.B., and Ferreira, D. (2007), A theory of friendly boards, Journal of Finance, 12, pp. 51-91. 
[4] Adams, R. (2003) What do boards do? Evidence from board committee and director compensation data. Unpublished working paper. Federal Reserve Bank of New York, New York, NY.

[5] Angrist, J.D., and Pischke, J.S. (2008) Mostly harmless econometrics: An empiricist's companion,. Princeton, N.J., Princeton University Press

[6] Anton, W.R.Q., Deltas, G., and Khanna, M. (2004) Incentives for environmental self regulation and implications for environmental performance, Journal of Environmental Economics and Management, 48, pp. 632-654.

[7] Berrone, P., and Gomez-Mejia, L. (2009) Environmental performance and executive compensation: an integrated agency-institutional perspective, Academy of Management Journal, 52, pp. 103-126.

[8] Billmoria, D. and Piderit, S.K. (1994) Board committee membership: effects of sex-selected bias, The Academy of Management Journal, 37, pp. 1453-1477.

[9] Bizjak, J., Lemmon, M., and Whitby, R. (2009) Option backdating and board interlocks, Review of Financial Studies, 22, pp. 4281-4847.

[10] Bryd, J.W., and Hickman, K.A. (1992) Do outside directors monitor managers? Journal of Financial Economics, 32, pp. 195-221.

[11] Coles, J.L., Daniel, N.D., and Naveen, L. (2008) Boards: Does one size fit all? Journal of Financial Economics, 87, pp. 329-356.

[12] Dasgupta, S., Hettige, H., and Wheeler, D. (2000) What improves environmental performance: evidence from Mexican industry, Journal of Environmental Economics and Management, 39, pp.39-66.

[13] Dass, N., Kini, O., Nanda, V., Onal, B., and Wang, J. (2014) Board expertise: Do directors from related industries help bridge the information gap? Review of Financial Studies, 27, pp. 1533-1592. 
[14] de Villiers, C., Naiker, V., and van Standen, C.J. (2011) The effect of board characteristics on environmental performance, Journal of Management, 37, pp. 1636-1663.

[15] Di Giuli, A. and Kostovetsky, L. (2014) Are red or blue companies more likely to go green? Journal of Financial Economics, 111(1), pp: 158-80.

[16] Eichholtz, P., Kok, N., and Quigley, J.M. (2010) Doing Well by Doing Good? Green Office Buildings, American Economic Review, 100(5), 2492-2509.

[17] Fama, E., and Jensen, M.C. (1983) Separation of ownership and control, Journal of Law and Economics, 26, pp. 301-325.

[18] Fich, E.M., and Shivdasani, A. (2006) Are busy boards effective monitors? Journal of Finance, 61, pp. 689-724.

[19] Fich, E.M., and White, L.J. (2003) CEO Compensation and Turnover: The Effects of Mutually Interlocked Boards, Wake Forest Law Review, 38(3), 933-959.

[20] Fisher-Vanden, K. and Thorburn, K.S. (2011) Voluntary corporate environmental initiatives and shareholder wealth, Journal of Environmental Economics and Management, 62(3), pp. $430-445$.

[21] Galasso, A., and T. Simcoe, 2011, CEO Overconfidence and Innovation, Management Science $57,1469-1484$.

[22] Garmaise, M., and Moskowitz, T. (2003) Informal financial networks: theory and evidence, Review of Financial Studies, 16, pp. 1007-1040.

[23] Gomes-Casseres, B., J. Hagedoorn and A. Jaffe, 2006, Do Alliances Promote Knowledge Flows?, Journal of Financial Economics, 80, 5-33.

[24] Goldman, E., Rocholl, J., and So, J. (2009) Do politically connected boards affect firm value? Review of Financial Studies, 22, pp. 2231-2260. 
[25] Güner, B.A., Malmendier, U., and Tate, G. (2008) Financial expertise of directors, Journal of Financial Economics, 88, pp. 323-354.

[26] Hamilton, J.T. (1995) Pollution as news: media and stock market reactions to the Toxics Release Inventory data, Journal of Environmental Economics and Management, 28, pp. $98-113$

[27] Hochberg, Y., Ljungqvist, A., and Lu, Y. (2007) Whom you know matters: Venture Capital Networks and Investment Performance, The Journal of Finance, LXII(1): 251-301.

[28] Hwang, B-H. and Kim, S. (2009) It Pays to Have Friends, Journal of Financial Economics,

[29] Jackson, M. O. (2010) Social and Economic Network, Princeton: Princeton University Press.

[30] Johnson, R. A., and Greening, D.W. (1999) The effects of corporate governance and institutional ownership types on corporate social performance, Academy of Management Journal, 42(5): 564-577.

[31] Karpoff, J.M., Lott, J.R., and Rankine, G. (1999) Environmental Violations, Legal Penalties, and Reputation Costs, John M. Olin Programme in Law and Economics Working paper No: 71 .

[32] Kassinis, G., and Vafeas, N. (2002) Corporate boards and outside stakeholders as determinats of environmental litigation, Strategic Management Journal, 23, pp. 399-415.

[33] King, A.A., and Lenox , M.J.(2000) Industry self-regulation without sanctions: the chemical industry's responsible care program, The Academy of Management Journal, 43, pp. 698-716.

[34] Klassens, R. and McLaughlin. (1996) The Impact of Environmental Management on Firm Performance, Management Science, 42(8), p. 1199-1214.

[35] Konar, S. and Cohen, M.A. (2001) Does the market value environmental performance? Review of Economics and Statistics, 83(2), pp. 281-289. 
[36] Larcker, D.F., So, E.C., and Wang, C.C.Y. (2013) Boardroom Centrality and Firm Performance, Journal of Accounting and Economics, 55(), pp. 225-250.

[37] Laux, C., and Laux, V. (2009) Board committees, CEO compensation, and earnings management, The Accounting Review, 84, pp. 869-891.

[38] Lindsey, L. (2008) Blurring firm boundaries: the role of venture capital in strategic alliances, Journal of Finance, 63, 1137-1168.

[39] Masulis, R.W., and Mobbs, S. (2011) Are all inside directors the same? CEO entrenchment and board entrenchment, Journal of Finance, 66, pp. 823-872.

[40] McKendall, M., Sánchez, C.M., and Sicilian, P. (1999) Corporate governance and corporate illegality: the effects of board structure on environmental violations, International Journal of Organizational Analysis, 7, pp. 201-223.

[41] Ortiz-de-Mandojana, N., Aragón-Correa, J. A., Delgado-Ceballos, J., and Ferrón-Vílchez, V. (2012) The effect of Director Interlocks on Firms' Adoption of Proactive Environmental Strategies, Corporate Governance: An International Review, 20(2): 164-178.

[42] Pfeffer, J., and Salancik, G. R. (1978) The external control of organizations: A resource dependence perspective, New York: Harper \& Row.

[43] Walls, J.L., Berrone, P., and Phan, P.H. (2012) Corporate Governance and Environmental Performance: Is there really a link? Strategic Management Journal, 33(8), pp. 885-913. 
Table I. Descriptive Statistics of Key Variables

This table shows descriptive statistics for the key variables of our sample

firms. All monetary values are expressed in constant 2010 US\$.

\begin{tabular}{|c|c|c|c|c|}
\hline & $\mathrm{N}$ & Mean & Median & Std. Dev. \\
\hline $\mathrm{ROA}$ & 3,244 & 7.802 & 6.126 & 6.546 \\
\hline Ln Sales & 3,244 & 17.422 & 11.215 & 6.874 \\
\hline Leverage & 3,244 & 0.556 & 0.511 & 0.0282 \\
\hline Volatility & 3,244 & 0.039 & 0.044 & 0.021 \\
\hline GHG Emissions (/1000 tonnes) & 3,244 & 2374.649 & 1079.810 & 1029.737 \\
\hline $\mathrm{R} \& \mathrm{D}$ & 3,244 & 0.049 & 0.003 & 0.033 \\
\hline HHI & 3,244 & 0.211 & 0.203 & 0.194 \\
\hline \%Shareholding-Institutions & 3,244 & 28.242 & 22.108 & 20.491 \\
\hline Board Size & 3,244 & 8.143 & 7.988 & 2.660 \\
\hline$\%$ Non-Executive Directors & 3,244 & 55.309 & 51.342 & 24.143 \\
\hline EED Dummy & 3,244 & 0.094 & 0.000 & 0.144 \\
\hline CEO Duality & 3,244 & 0.230 & 0.000 & 0.301 \\
\hline Degree & 3,244 & 8.237 & 4.133 & 5.988 \\
\hline Closeness & 3,244 & 0.286 & 0.202 & 0.026 \\
\hline Betweenness & 3,244 & 0.012 & 0.029 & 0.012 \\
\hline Eigen Vector & 3,244 & 0.043 & 0.067 & 0.045 \\
\hline
\end{tabular}


Table II. Industry Composition of the Sample

This table provides the average network centrality measures and GHG emissions of sample fir -ms, by the main industries

\begin{tabular}{|c|c|c|c|c|c|c|}
\hline Industry & No. of Firms & $\begin{array}{l}\text { Environmental } \\
\text { Directors (No.) }\end{array}$ & GHG & Degree & Closeness & Eigenvector \\
\hline Energy & 23 & 131 & 3039.281 & 5.982 & 0.122 & 0.057 \\
\hline Industrial & 82 & 78 & 2812.973 & 9.338 & 0.254 & 0.040 \\
\hline FMCG & 77 & 82 & 1008.653 & 8.979 & 0.231 & 0.047 \\
\hline Pharmaceuticals & 31 & 110 & 1242.750 & 7.898 & 0.229 & 0.051 \\
\hline Healthcare & 38 & 72 & 844.195 & 8.395 & 0.212 & 0.048 \\
\hline Utilities & 23 & 88 & 1747.296 & 8.252 & 0.208 & 0.041 \\
\hline
\end{tabular}

Table III. Network Summary Statistics

In this table we present the firm-level network centrality measures accross the sam -ple period. The average network centrality measures are relatively stable over time and the number of connections increase.

\begin{tabular}{lrrrrrrrr}
\hline & 2007 & 2008 & 2009 & 2010 & 2011 & 2012 & 2013 & 2014 \\
\hline No. of Firms & 353 & 353 & 354 & 356 & 353 & 352 & 354 & 354 \\
No. of Directors & 1,254 & 1,372 & 1,029 & 1,003 & 950 & 1,026 & 885 & 961 \\
No. of Connections & 458 & 503 & 524 & 528 & 616 & 562 & 663 & 624 \\
Mean Degree & 6.235 & 6.978 & 6.381 & 6.500 & 6.648 & 6.614 & 6.137 & 5.981 \\
Mean Closeness & 0.269 & 0.273 & 0.201 & 0.271 & 0.268 & 0.279 & 0.274 & 0.275 \\
Median Betweenness & 0.017 & 0.016 & 0.017 & 0.015 & 0.016 & 0.012 & 0.014 & 0.012 \\
\hline
\end{tabular}


Table IV. Univariate Comparison of Firms with and without EEDs

In this table we compare firm-years with EEDs and without. Firms with EEDs have , on average, larger boards, lower degree of connectivity, and lower GHG emission s. ${ }^{* *}, * *$, and $*$ represent significance at $1 \%, 5 \%$ and $10 \%$ level, respectively. The significance is based on a two-tailed $t$-test.

\begin{tabular}{|c|c|c|c|}
\hline & \multicolumn{2}{|c|}{ Means } & \multirow[b]{3}{*}{ Difference } \\
\hline & Firms with & Firms without & \\
\hline & EEDs & EEDs & \\
\hline $\mathrm{ROA}$ & 7.214 & 7.988 & -0.784 \\
\hline Ln Sales & 17.248 & 17.507 & -0.259 \\
\hline Leverage & 0.575 & 0.560 & 0.015 \\
\hline Volatility & 0.034 & 0.040 & -0.006 \\
\hline GHG Emissions (/1000 tonnes) & 2008.120 & 2518.788 & $-510.668^{* * *}$ \\
\hline $\mathrm{R} \& \mathrm{D}$ & 0.049 & 0.047 & 0.002 \\
\hline $\mathrm{HHI}$ & 0.203 & 0.214 & -0.011 \\
\hline \%Shareholding-Institutions & 30.018 & 28.503 & 1.515 \\
\hline Board Size & 8.648 & 7.501 & $1.147^{* *}$ \\
\hline$\%$ Non-Executive Directors & 55.013 & 55.304 & -0.291 \\
\hline CEO Duality & 0.228 & 0.235 & -0.007 \\
\hline Degree & 7.225 & 8.543 & $-1.318^{* *}$ \\
\hline Closeness & 0.288 & 0.285 & 0.003 \\
\hline Betweenness & 0.015 & 0.011 & 0.004 \\
\hline Eigen Vector & 0.049 & 0.039 & 0.010 \\
\hline
\end{tabular}


Figure 1

This figure presents the time series of aggregate supply of EEDs and average GHG emissions of our sample firms. There is no evidence that these two serie -s are co-integrated. We use the supply of EEDs as an instrument for firm-lev -el appointments of EEDs.

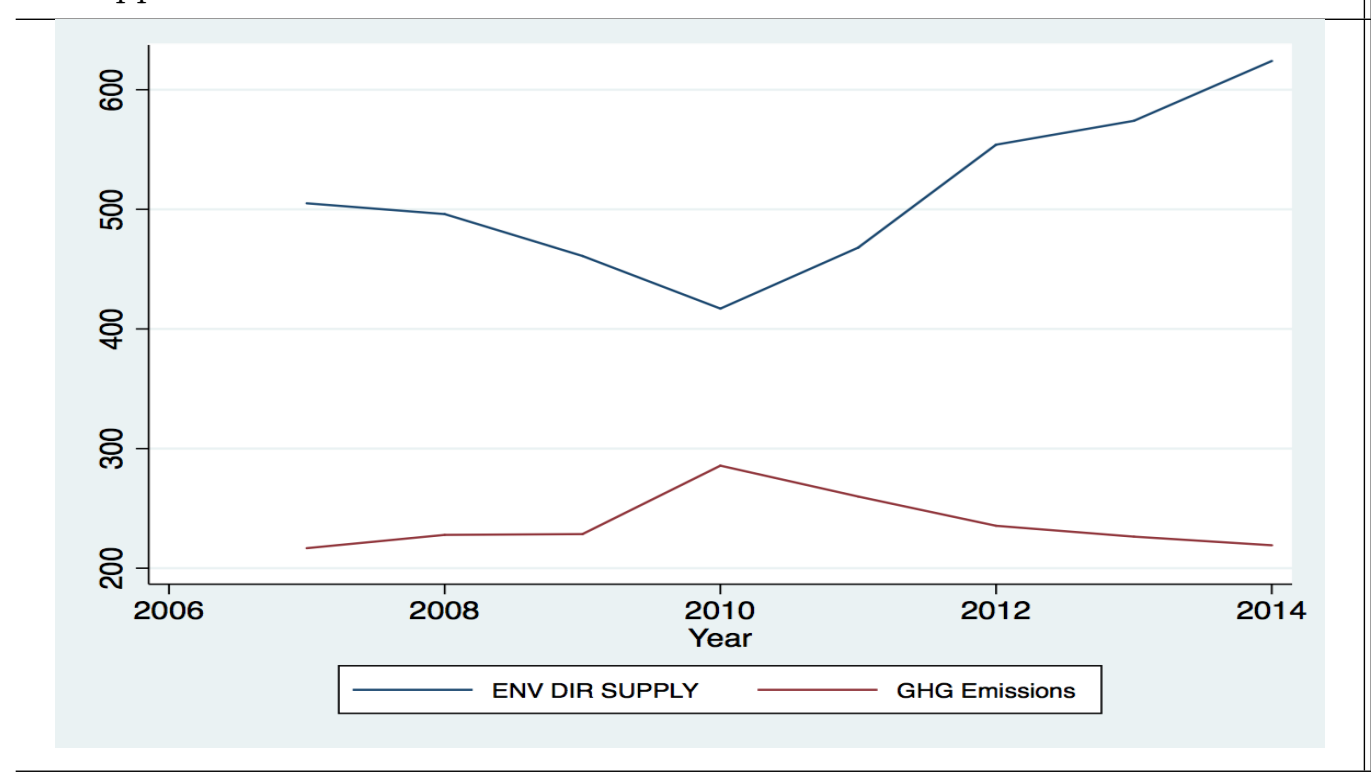


Table V. Director Experience and GHG Emissions

In this table we present the baseline estimates of board expertise in environmetal sustainability and GHG emissions. In column 1 we use a binary indicator of at least one director with environmental experience (EED), in column 2 we add a binary indicator for presence of a board committee on environmental sustainability, and in column 3 we further add an interaction of EED and environmen -tal committees. The results suggest the board expertise and the presence of co-mmittees on environmental issues are associated with lower GHG emissions.

Robust standard errors clustered at firm the firm level is given in brackets. *** **, and * indicate significance at the $1 \%, .5 \%$ and $10 \%$ level, respectively.

\begin{tabular}{|c|c|c|c|}
\hline & \multicolumn{3}{|c|}{ Dependent Variable: $G H G$ Emissions } \\
\hline & (1) & $(2)$ & $(3)$ \\
\hline \multirow[t]{2}{*}{ EED dummy } & $-0.027^{* *}$ & $-0.021 * *$ & $-0.015^{* *}$ \\
\hline & $(0.013)$ & $(0.009)$ & $(0.007)$ \\
\hline \multirow[t]{2}{*}{ Environmental Committees } & & $-0.011^{* *}$ & $-0.010^{* *}$ \\
\hline & & $(0.004)$ & $(0.005)$ \\
\hline EED * Environmental & & & $-0.029^{* *}$ \\
\hline Committees & & & $(0.010)$ \\
\hline \multirow[t]{2}{*}{ \%Shareholding-Institutions } & $-0.023^{* *}$ & $-0.016^{* *}$ & $-0.011^{* *}$ \\
\hline & $(0.011)$ & $(0.008)$ & $(0.005)$ \\
\hline \multirow[t]{2}{*}{ Board Size } & 0.019 & 0.016 & 0.014 \\
\hline & $(0.013)$ & $(0.012)$ & $(0.009)$ \\
\hline \multirow[t]{2}{*}{$\%$ Non-Executive Directors } & 0.024 & 0.019 & 0.017 \\
\hline & $(0.017)$ & $(0.010)$ & $(0.013)$ \\
\hline \multirow[t]{2}{*}{ LogSales } & $0.016^{* *}$ & 0.012 & 0.013 \\
\hline & $(0.007)$ & $(0.009)$ & $(0.010)$ \\
\hline \multirow[t]{2}{*}{ ROA } & 0.004 & 0.006 & 0.001 \\
\hline & $(0.003)$ & $(0.005)$ & $(0.003)$ \\
\hline \multirow[t]{2}{*}{ Leverage } & -0.004 & -0.000 & -0.001 \\
\hline & $(0.008)$ & $(0.002)$ & $(0.002)$ \\
\hline \multirow[t]{2}{*}{ Volatility } & 0.008 & 0.006 & 0.006 \\
\hline & $(0.013)$ & $(0.009)$ & $(0.008)$ \\
\hline \multirow[t]{2}{*}{$\mathrm{R} \& \mathrm{D}$} & -0.019 & -0.015 & -0.015 \\
\hline & $(0.021)$ & $(0.017)$ & $(0.015)$ \\
\hline \multirow[t]{2}{*}{ CEO Duality } & 0.134 & 0.139 & 0.138 \\
\hline & $(0.122)$ & $(0.129)$ & $(0.116)$ \\
\hline \multirow[t]{2}{*}{ HHI } & -0.123 & 0.120 & 0.120 \\
\hline & $(0.104)$ & $(0.100)$ & $(0.108)$ \\
\hline Year Dummies & Yes & Yes & Yes \\
\hline Industry Dummies & Yes & Yes & Yes \\
\hline Firm Fixed Effects & Yes & Yes & Yes \\
\hline \multirow[t]{2}{*}{ Constant } & $0.221^{* * *}$ & $0.218^{* * *}$ & $0.206^{* * *}$ \\
\hline & $(0.033)$ & $(0.041)$ & $(0.059)$ \\
\hline Observations & 3,244 & 3,244 & 3,244 \\
\hline Adjusted- $R^{2}$ & 0.231 & 0.240 & 0.249 \\
\hline
\end{tabular}


Table VI. Director Experience and GHG Emissions: Controlling for Endogeneity

In this table we present endogeneity-adjusted results for director expertise (EED) and GHG emissions. In table 1 we present the first stage results with Ln (Supply per Seat) of environmental directors as the instrument for firm level appointments of EEDs. In columns (2)-(4) we present the different specifications of the second-stage regression. The F-stats from the first stage is over 20, mitigating concerns about weak instrument. The parameter estimate on the instrument is positively associated with EED appointm-ents, and is statistically significant. Controlling for endogeneity the basline results hol -d: board expertise is associated with lower GHG emissions. Robust standard errors clustered at firm levels are given in brackets. ${ }^{* * *},{ }^{* *}$, and ${ }^{*}$ indicate significance at 1 $\%, .5 \%$ and $10 \%$ level, respectively.

\begin{tabular}{lcccc}
\hline & \multicolumn{4}{c}{ Dependent Variables: } \\
\cline { 2 - 5 } & EED & $(2)$ & $(3)$ & $(4)$ \\
\cline { 2 - 5 } Ln (Supply Per Seat) & & & & \\
& & & & \\
& & & & \\
EED dummy & $(0.079)$ & & $-0.021^{* * *}$ & $-0.015^{* *}$ \\
& & $-0.022^{* *}$ & $(0.009)$ & $(0.007)$ \\
Environmental Committees & & $(0.011)$ & $-0.011^{* *}$ & $-0.010^{* *}$ \\
& & & $(0.004)$ & $(0.005)$ \\
EED * Environmental & & & & $-0.029^{* *}$ \\
Committees & & & & $(0.010)$ \\
Control Variables & Yes & Yes & Yes & Yes \\
Year Dummies & Yes & Yes & Yes & Yes \\
Industry Dummies & Yes & Yes & Yes & Yes \\
Firm Fixed Effects & Yes & Yes & Yes & Yes \\
Constant & $0.221^{* * *}$ & $0.223^{* * *}$ & $0.218^{* * *}$ & $0.206^{* * *}$ \\
& $(0.033)$ & $(0.060)$ & $(0.041)$ & $(0.059)$ \\
Observations & 3,244 & 3,244 & 3,244 & 3,244 \\
Adjusted- $R^{2}$ & 0.231 & 0.237 & 0.240 & 0.249 \\
\hline
\end{tabular}


Table VII. Board Centrality and GHG Emissions

In this table we present the results of the estimates for board centrality measures and environmental performance. Column 1 presents the results with degree centrality, wi -thout firm and year fixed effects. Columns $2-5$ present the fixed-effects results wi-th four measures of board centrality: Degree, Closeness, Betweenness, and Eigenve -ctor. The estimate on degree is statistically significant in column 2 but overall our results suggest that better-networked boards have lower GHG emissions. Robust stan -dard errors clustered at the firm level are given in brackets. ${ }^{* * *},{ }^{*}$, and $*$ indicate significance at the $1 \%, .5 \%$ and $10 \%$ level, respectively.

\begin{tabular}{|c|c|c|c|c|c|}
\hline & (1) & $\begin{array}{c}\text { Dependent } \\
\text { (2) }\end{array}$ & $\begin{array}{c}\text { ariable: } G \\
(3)\end{array}$ & $\begin{array}{c}G \text { Emissions } \\
(4)\end{array}$ & $(5)$ \\
\hline Degree & $\begin{array}{c}-0.033^{*} \\
(0.017)\end{array}$ & $\begin{array}{r}-0.021 \\
(0.015)\end{array}$ & & & \\
\hline Closeness & & & $\begin{array}{r}-0.047^{* *} \\
(0.23)\end{array}$ & & \\
\hline Betweenness & & & & $\begin{array}{c}-0.031^{* *} \\
(0.014)\end{array}$ & \\
\hline Eigen Vector & & & & & $\begin{array}{r}-0.012^{*} \\
(0.007)\end{array}$ \\
\hline \%Shareholding-Institutions & $\begin{array}{r}-0.031^{* *} \\
(0.014)\end{array}$ & $\begin{array}{r}-0.020^{* *} \\
(0.008)\end{array}$ & $\begin{array}{r}-0.019^{* *} \\
(0.008)\end{array}$ & $\begin{array}{c}-0.017^{* *} \\
(0.007)\end{array}$ & $\begin{array}{c}-0.0012^{* *} \\
(0.006)\end{array}$ \\
\hline Board Size & $\begin{array}{r}0.017 \\
(0.015)\end{array}$ & $\begin{array}{r}0.013 \\
(0.009)\end{array}$ & $\begin{array}{r}0.014 \\
(0.008)\end{array}$ & $\begin{array}{c}0.011 \\
(0.009)\end{array}$ & $\begin{array}{c}0.013 \\
(0.009)\end{array}$ \\
\hline \% Non-Executive Directors & $\begin{array}{r}0.031 \\
(0.021)\end{array}$ & $\begin{array}{r}0.023 \\
(0.012)\end{array}$ & $\begin{array}{r}0.025 \\
(0.015)\end{array}$ & $\begin{array}{c}0.024 \\
(0.015)\end{array}$ & $\begin{array}{c}0.026 \\
(0.018)\end{array}$ \\
\hline LogSales & $\begin{array}{l}0.024^{* *} \\
(0.011)\end{array}$ & $\begin{array}{c}0.018^{*} \\
(0.010)\end{array}$ & $\begin{array}{c}0.014^{*} \\
(0.007)\end{array}$ & $\begin{array}{l}0.012^{*} \\
(0.007)\end{array}$ & $\begin{array}{l}0.018^{*} \\
(0.009)\end{array}$ \\
\hline ROA & $\begin{array}{c}0.008 \\
(0.006)\end{array}$ & $\begin{array}{c}0.006 \\
(0.004)\end{array}$ & $\begin{array}{c}0.002 \\
(0.002)\end{array}$ & $\begin{array}{c}0.004 \\
(0.003)\end{array}$ & $\begin{array}{c}0.004 \\
(0.004)\end{array}$ \\
\hline Leverage & $\begin{array}{r}-0.009 \\
(0.008)\end{array}$ & $\begin{array}{r}-0.009 \\
(0.009)\end{array}$ & $\begin{array}{r}-0.008 \\
(0.008)\end{array}$ & $\begin{array}{r}-0.002 \\
(0.002)\end{array}$ & $\begin{array}{r}-0.000 \\
(0.002)\end{array}$ \\
\hline Volatility & $\begin{array}{r}0.009 \\
(0.018)\end{array}$ & $\begin{array}{r}0.009 \\
(0.019)\end{array}$ & $\begin{array}{r}0.006 \\
(0.015)\end{array}$ & $\begin{array}{r}0.006 \\
(0.009)\end{array}$ & $\begin{array}{r}0.006 \\
(0.009)\end{array}$ \\
\hline $\mathrm{R} \& \mathrm{D}$ & $\begin{array}{r}-0.019 \\
(0.020)\end{array}$ & $\begin{array}{r}-0.017 \\
(0.015)\end{array}$ & $\begin{array}{r}-0.017 \\
(0.020)\end{array}$ & $\begin{array}{r}-0.013 \\
(0.014)\end{array}$ & $\begin{array}{c}-0.014 \\
(0.016)\end{array}$ \\
\hline CEO Duality & $\begin{array}{r}0.132 \\
(0.134)\end{array}$ & $\begin{array}{r}0.130 \\
(0.122)\end{array}$ & $\begin{array}{r}0.122 \\
(0.128)\end{array}$ & $\begin{array}{r}0.129 \\
(0.125)\end{array}$ & $\begin{array}{r}0.140 \\
(0.126)\end{array}$ \\
\hline $\mathrm{HHI}$ & $\begin{array}{r}-0.126 \\
(0.118)\end{array}$ & $\begin{array}{r}0.127 \\
(0.110)\end{array}$ & $\begin{array}{r}-0.122 \\
(0.108)\end{array}$ & $\begin{array}{r}0.117 \\
(0.102)\end{array}$ & $\begin{array}{r}0.118 \\
(0.111)\end{array}$ \\
\hline Year Dummies & No & Yes & Yes & Yes & Yes \\
\hline Industry Dummies & No & Yes & Yes & Yes & Yes \\
\hline Firm Fixed Effects & No & Yes & Yes & Yes & Yes \\
\hline Constant & $\begin{array}{r}0.238^{* * *} \\
(0.045)\end{array}$ & $\begin{array}{r}0.202^{* * *} \\
(0.033)\end{array}$ & $\begin{array}{r}0.191^{* * *} \\
(0.039)\end{array}$ & $\begin{array}{c}0.212^{* * *} \\
(0.048)\end{array}$ & $\begin{array}{c}0.200^{\text {*** }} \\
(0.041)\end{array}$ \\
\hline Observations & 3,244 & 3,244 & 3,244 & 3,244 & 3,244 \\
\hline Adjusted- $R^{2}$ & 0.013 & 0.019 & 0.027 & 0.025 & 0.021 \\
\hline
\end{tabular}


Table VIII. Board Composition and GHG Emissions: Controlling for Endogeneity In this table we present the results of the estimates for board centrality and GHG emissions, controlling for potential endogeneous board formation. Panel A provides estimates with subsample of firms with unchanged board composition from $t-1$ to $t$, and panel B presents the results for subsample of firms with unchanged board composition and first-degree connections from $t-1$ to $t$. Robust standard errors clustered at the firm level are given in brackets. $* * *, * *$, and $*$ indicate significance at the $1 \%, .5 \%$ and $10 \%$ level, respectively.

\begin{tabular}{|c|c|c|c|c|c|}
\hline . & $(1)$ & $\begin{array}{c}(2) \\
\text { Dependent }\end{array}$ & $\begin{array}{c}\text { (3) } \\
\text { ariable: } G H\end{array}$ & $\begin{array}{l}(4) \\
G \text { Emissions }\end{array}$ & $(5)$ \\
\hline \multicolumn{6}{|c|}{ Panel A: Regressions with Unchanged Board Sample } \\
\hline Degree & $\begin{array}{r}-0.017 \\
(0.014)\end{array}$ & - & - & - & - \\
\hline Closeness & - & $\begin{array}{r}-0.035^{* *} \\
(0.018)\end{array}$ & - & - & - \\
\hline Betweenness & - & - & $\begin{array}{c}-0.020^{* *} \\
(0.010)\end{array}$ & - & - \\
\hline Eigen Vector & - & - & - & $\begin{array}{c}-0.009^{*} \\
(0.005)\end{array}$ & - \\
\hline EED dummy & - & - & - & - & $\begin{array}{r}-0.011^{* *} \\
(0.005)\end{array}$ \\
\hline Environmental Committees & - & - & - & - & $\begin{array}{r}-0.009^{* *} \\
(0.004)\end{array}$ \\
\hline EED* & - & - & - & - & $-0.023^{* *}$ \\
\hline Environmental Committees & & & & & $(0.011)$ \\
\hline Firm Covariates & Yes & Yes & Yes & Yes & Yes \\
\hline Year Dummies & Yes & Yes & Yes & Yes & Yes \\
\hline Industry Dummies & Yes & Yes & Yes & Yes & Yes \\
\hline Firm Fixed Effects & Yes & Yes & Yes & Yes & Yes \\
\hline Constant & $\begin{array}{c}0.191^{* * *} \\
(0.044)\end{array}$ & $\begin{array}{c}0.197^{* * *} \\
(0.039)\end{array}$ & $\begin{array}{c}0.186^{* * *} \\
(0.051)\end{array}$ & $\begin{array}{c}0.194^{* * *} \\
(0.047)\end{array}$ & $\begin{array}{c}0.207^{* * *} \\
(0.033)\end{array}$ \\
\hline \multicolumn{6}{|c|}{ Panel B: Regressions with unchanged board and first-degree links } \\
\hline Degree & $\begin{array}{r}0.019 \\
(0.013)\end{array}$ & - & - & - & - \\
\hline Closeness & - & $\begin{array}{r}0.041^{* *} \\
(0.20)\end{array}$ & - & - & - \\
\hline Betweenness & - & - & $\begin{array}{c}0.036^{* *} \\
(0.012)\end{array}$ & - & - \\
\hline Eigen Vector & - & - & - & $\begin{array}{c}0.017^{* *} \\
(0.008)\end{array}$ & - \\
\hline EED dummy & - & - & - & - & $\begin{array}{r}0.017^{* *} \\
(0.005)\end{array}$ \\
\hline Environmental Committees & - & - & - & - & $\begin{array}{r}0.012^{* *} \\
(0.004)\end{array}$ \\
\hline $\begin{array}{l}\text { EED* } \\
\text { Environmental Committees }\end{array}$ & - & - & - & - & $\begin{array}{r}0.035^{* *} \\
(0.016)\end{array}$ \\
\hline Firm Covariates & Yes & Yes & Yes & Yes & Yes \\
\hline Year Dummies & Yes & Yes & Yes & Yes & Yes \\
\hline Industry Dummies & Yes & Yes & Yes & Yes & Yes \\
\hline Firm Fixed Effects & Yes & Yes & Yes & Yes & Yes \\
\hline Constant & $\begin{array}{c}0.152^{* * *} * \\
(0.061)\end{array}$ & $\begin{array}{c}0.158^{* * * *} \\
(0.057)\end{array}$ & $\begin{array}{c}0.147^{* * * *} \\
(0.063)\end{array}$ & $\begin{array}{c}0.150^{* * * *} \\
(0.072)\end{array}$ & $\begin{array}{c}0.203^{* * *} \\
(0.063)\end{array}$ \\
\hline
\end{tabular}


Table IX. Robustness to classifications of EEDs

In this table we present the results of our robustness tests. In column 1 we examine the effect of technical expertise of dirctors on environmental performance, and find no statistically significant effect; in column 2 we present the results for CEO -EEDs, and in column 3 for non-CEO EEDs, separately. We find that both types of EEDs are associated with lower GHG emissions. Robust standard errors clustered at the firm level are given in the parentheses. ${ }^{* * *}, * *$, and $*$ indicate significance at the $1 \%, 5 \%$ and $10 \%$ levels, respectively.

Dependent Variable: GHG Emissions

Technical Directors $\quad-0.007$

CEO-EEDs $-0.011^{* *}$

Non-CEO EEDs $-0.021^{* *}$

\begin{tabular}{lccc} 
Firm Covariates & Yes & Yes & Yes \\
Year Dummies & Yes & Yes & Yes \\
Industry Dummies & Yes & Yes & Yes \\
Firm Fixed Effects & Yes & Yes & Yes \\
Constant & $0.179^{* * *}$ & $0.189^{* * *}$ & $0.206^{* * *}$ \\
& $(0.033)$ & $(0.055)$ & $(0.065)$ \\
\hline
\end{tabular}




\section{Appendix I: GHG Emissions Algorithm}

As a measure of firms' environmental performance, we use firms' GHG emission data from the E-PRTR (Website: http://prtr.ec.europa.eu/). The E-PRTR is the Europe-wide register that provides annual data on the amounts of pollutant releases to air, water and land from 93 key pollutants (e.g. heavy metals, pesticides, greenhouse gases and dioxins) as well as offsite transfers of waste and of pollutants in waste water from 43,464 industrial facilities in the EU Member States, Iceland, Liechtenstein, Norway, Serbia and Switzerland over the period 2007-2012. The main advantage of the register is that data is comparable across countries and pollutants because data collection and reporting is standardised over all pollutants in all countries. A facility is defined as n operation unit of a firm focused on a narrowly defined process like packaging, bottling, etc.

Our original dataset downloaded from the E-PRTR website contains 561,075 observations. Each line of the dataset reports data on one particular pollutant released/transferred by one facility in one year as well as information about the category of the pollutant (greenhouse gas, pesticide...) and information about the facility (e.g. address, activity sector, parent company, etc.). As a consequence, we may have several observations for the same facility within a year if this facility releases or transfers various types of pollutants per year. For example, the facility with ID = 9 (Saint-Gobain Glass Polska Sp. Z o. o.) has three lines for the year 2011 in the

dataset because this facility released two types of pollutant (NOx and Cadmium) and reported hazardous waste disposal in 2011.

As we are not interested in one particular pollutant we will aggregate pollutants in 7 categories defined on the E-PRTR website:Chlorinated organic substances, greenhouse gases (our variable of interest), heavy metals, inorganic substances, other gases, other organic substances, pesticides. We have also two categories for waste: hazardous and non-hazardous. Since the harmfulness of each pollutant differs and also the relative amount of each pollutant emitted differs, we cannot simply add the individual amounts of pollutant to aggregate them in these 7 categories.

Each pollutant is reported in the E-PRTR if the emitted amount exceeds a reporting thresh- 
old. The reporting thresholds are set up by the European Commission based on their impact on human health and on the environment ${ }^{8}$ We therefore normalize the emitted amount according to the reporting threshold and then sum these normalized amounts of pollutant belonging to the same category for each individual facility.

We finally reshape the dataset to have only one observation per facility per year. Our dataset has now 208,735 lines. Each line contains information on the facility (address, parent company and economic activity code) and the amount of pollutant by category.

\footnotetext{
${ }^{8}$ See Article 5 of the E-PRTR Regulation No 166/2006 of the European Parliament and of the Council of 18 January 2006 concerning the establishment of a European Pollutant Release and Transfer Register and amending Council Directives 91/689/EEC and 96/61/EC. http://eur-lex.europa.eu/LexUriServ/LexUriServ.do?uri=OJ: L:2006:033:0001:0017:EN:PDF
} 


\section{Appendix II: Board Expertise Algorithm}

To identify directors with environmental expertise, we use data from BoardEx on the education and past expertise of directors in matters related to environmental sustainability. We classify directors as having prior experience in environmental issues if they have served on any of the following board level committees in a previous role:

1. Health, Safety, Security, and Environment

2. Safety and Sustainable Development

3. Sustainability and Stakeholder Management

4. Corporate Responsibility

5. Sustainability

6. Safety, Ethics, and Environmental Assurance

7. Corporate Social Responsibility

8. Sustainable and Responsible Business

9. Health, Safety, Environment and Community

10. Ethics-Compliance-Corporate Responsibility

11. Safety, Health, and Environment

12. Sustainable Development

13. Risk and CSR

14. Environment, Health and Safety

15. CSR and Regulatory Issues

16. Corporate Compliance and Responsibility 
In order to test for the robustness of our results, we also construct different measures by random sampling of these keywords. Data on EEDs are available from the authors' websites on request.

\section{Appendix III: Board Network Algorithm}

The concept of centrality is multi-dimensional. In this paper, we focus on the four commonly used measures of centrality (see Jackson, 2010 and Larcker, So, and Wang, 2013): Degree, Eigenvector, Closeness and Betweenness. We compute these measures for each director in the network formed by shared directorship. To aggregate these measures at the board level, we compute the average centrality measures of the directors of the board. We discuss the relevance of each of these measures below:

\section{Degree}

The simplest centrality measure is the count of the number of connections. The degree is similar to the concept of board interlock used in the literature about the impact of board governance. A higher degree reflects more pathways to access to information, and expertise. The degree centrality varies over time due to entry and exit of directors, and is normalised by $n-1, n$ where is the number of directors in the network.

$$
\text { Degree }_{i}=\sum_{j \neq i} d_{i j}
$$

$d_{i j}$ is equal to 1 if directors $i$ and $j$ sit on the same board and 0 otherwise.

\section{Eigenvector}

It can be argued that a director is more influential when his individual connections are also well-networked. Unlike degree, which weights every link equally, the eigenvector weights links according to their eigenvector values. A nodes' eigenvector is proportional to the sum of

the eigenvector values of all nodes directly connected to it. It is useful in determining who is connected to the most connected nodes. The eigenvector of a node is defined as 


$$
e_{i}=\lambda^{-1} \sum_{j \neq i} d_{i j} e_{j}
$$

where $\lambda$ is the eigenvalue. In our context, it is important to measure how central a director is in terms of its own degree but it it also important to take into account the degrees of the directors he is connected to. If director $i$ is connected to director $j$, who is very well connected (i.e. has a high degree), then director $i$ has a greater opportunity to get access to information or influence the rest of network.

\section{Closeness}

This measures the ease to reach other nodes or how long it will take to spread information from one director to all other directors sequentially.

$$
\text { Closeness }_{i}=\frac{n-1}{\sum_{j \neq i} l_{i j}}
$$

Where $l_{i j}$ is the distance between directors $i$ and $j$.In our network, a high closeness indicates a director who is close to others and can therefore quickly interact and communicate with them without going through many intermediaries. High closeness makes information transmission quicker.

\section{Betweenness}

The betweenness of a node is a measure of its role as an intermediary. Formally, node $i$ betweenness is the sum of proportions for all pairs of nodes $j$ and $k$ in which node $i$ is on the shortest path between $j$ and $k$. It is normalized by the maximum possible betweenness for the network with $n$ nodes. Mathematically, It is defined as

$$
\text { Betweenness }_{i}=\sum_{j, k \neq i} \frac{P_{i}(j, k) / P(j, k)}{(n-1)(n-2) / 2}
$$


where $P(j, k)$ is the number of shortest paths between $j$ and $k$ and $P_{i}(j, k)$ is the number of shortest paths between $j$ and $k$ that goes through $i$. Directors with high betweenness are on the path of large number of information flows and as such, able to influence a large number of directors as well as be able to collect information quickly from many sources. 